University of Nebraska - Lincoln

DigitalCommons@University of Nebraska - Lincoln

1997

\title{
Late Holocene Eolian Activity in the Mineralogically Mature Nebraska Sand Hills
}

Daniel R. Muhs

U.S. Geological Survey, dmuhs@usgs.gov

Thomas W. Stafford Jr.

University of Colorado at Boulder

James B. Swinehart

University of Nebraska - Lincoln, jswinehart1@unl.edu

Scott D. Cowherd

U.S. Geological Survey

Shannon A. Mahan

U.S. Geological Survey

See next page for additional authors

Follow this and additional works at: https://digitalcommons.unl.edu/natrespapers

Part of the Natural Resources and Conservation Commons

Muhs, Daniel R.; Stafford, Thomas W. Jr.; Swinehart, James B.; Cowherd, Scott D.; Mahan, Shannon A.; Bush, Charles A.; Madole, Richard F.; and Maat, Paula B., "Late Holocene Eolian Activity in the Mineralogically Mature Nebraska Sand Hills" (1997). Papers in Natural Resources. 175.

https://digitalcommons.unl.edu/natrespapers/175

This Article is brought to you for free and open access by the Natural Resources, School of at DigitalCommons@University of Nebraska - Lincoln. It has been accepted for inclusion in Papers in Natural Resources by an authorized administrator of DigitalCommons@University of Nebraska - Lincoln. 


\section{Authors}

Daniel R. Muhs, Thomas W. Stafford Jr., James B. Swinehart, Scott D. Cowherd, Shannon A. Mahan, Charles A. Bush, Richard F. Madole, and Paula B. Maat 


\title{
Late Holocene Eolian Activity in the Mineralogically Mature Nebraska Sand Hills
}

\author{
Daniel R. Muhs \\ U.S. Geological Survey, MS 980, Box 25046, Federal Center, Denver, Colorado 80225
}

Thomas W. Stafford, Jr.

Center for Geochronological Research, Institute of Arctic and Alpine Research, Campus Box 450, University of Colorado, Boulder, Colorado 80309

James B. Swinehart

Conservation and Survey Division, 113 Nebraska Hall, University of Nebraska, Lincoln, Nebraska 68588

and

Scott D. Cowherd, Shannon A. Mahan, Charles A. Bush, Richard F. Madole, and Paula B. Maat

U.S. Geological Survey, MS 980, Box 25046, Federal Center, Denver, Colorado 80225

Received December 10, 1996

The age of sand dunes in the Nebraska Sand Hills has been controversial, with some investigators suggesting a full-glacial age and others suggesting that they were last active in the late Holocene. New accelerator mass spectrometry radiocarbon ages of unaltered bison bones and organic-rich sediments suggest that eolian sand deposition occurred at least twice in the past $3000{ }^{14} \mathrm{C} \mathrm{yr}$ B.P. in three widely separated localities and as many as three times in the past $800{ }^{14} \mathrm{C} \mathrm{yr}$ at three other localities. These late Holocene episodes of eolian activity are probably the result of droughts more intense than the 1930s "Dust Bowl" period, based on independent Great Plains climate records from lake sediments and tree rings. However, new geochemical data indicate that the Nebraska Sand Hills are mineralogically mature. Eolian sands in Nebraska have lower $\mathrm{K}$-feldspar (and $\mathrm{K}_{2} \mathrm{O}, \mathrm{Rb}$, and $\mathrm{Ba}$ ) contents than most possible source sediments and lower K-feldspar contents than dunes of similar age in Colorado. The most likely explanation for mineralogical maturity is reduction of sand-sized K-feldspar to silt-sized particles via ballistic impacts due to strong winds over many cycles of eolian activity. Therefore, dunes of the Nebraska Sand Hills must have had a long history, probably extending over more than one glacial-interglacial cycle, and the potential for reactivation is high, with or without a future greenhouse warming. () 1997 University of Washington.

\section{INTRODUCTION}

Extensive tracts of unconsolidated, stabilized dunes and sand sheets are found on the semiarid to subhumid Great
Plains of North America. The 50,000 km² Nebraska Sand Hills area is the largest dune field (active or stabilized) in the western hemisphere (Fig. 1). We report here new studies of Nebraska Sand Hills eolian history based on stratigraphy and accelerator mass spectrometry (AMS) ${ }^{14} \mathrm{C}$ dating of enclosed bison bones and underlying organic-rich alluvium. We also report mineralogical and geochemical studies of Sand Hills sediments that have implications for the longterm history of this sand sea.

A wide variety of stabilized eolian landforms are found in the Nebraska Sand Hills (Smith, 1965; Ahlbrandt and Fryberger, 1980; Swinehart, 1990). Barchanoid-ridge dunes are as much as $50 \mathrm{~km}$ long and are visible on Landsat imagery (Fig. 2). Barchans, linear dunes, parabolic dunes, dome-like dunes, and sand sheets are also all found in the Nebraska Sand Hills. Measurement of slipfaces of stabilized dunes and dip azimuths of high-angle foreset beds indicate that paleowinds originated from the northwest and north, similar to modern wind regimes (Warren, 1976; Ahlbrandt and Fryberger, 1980). Smaller dune fields are found in southwestern Nebraska and adjacent northeastern Colorado (Fig. 1), where the main eolian landforms are simple and compound parabolic dunes and older sand sheets (Madole, 1995; Muhs et al., 1996a).

Several investigators assert, or assume, that dunes in the Nebraska Sand Hills were last active on a large scale during the full-glacial period about 22,000-16,000 yr B.P. (Watts and Wright, 1966; Warren, 1976; Sarnthein, 1978; Wells, 1983; Kutzbach and Wright, 1985). In contrast, other investi-

All rights of reproduction in any form reserved. 


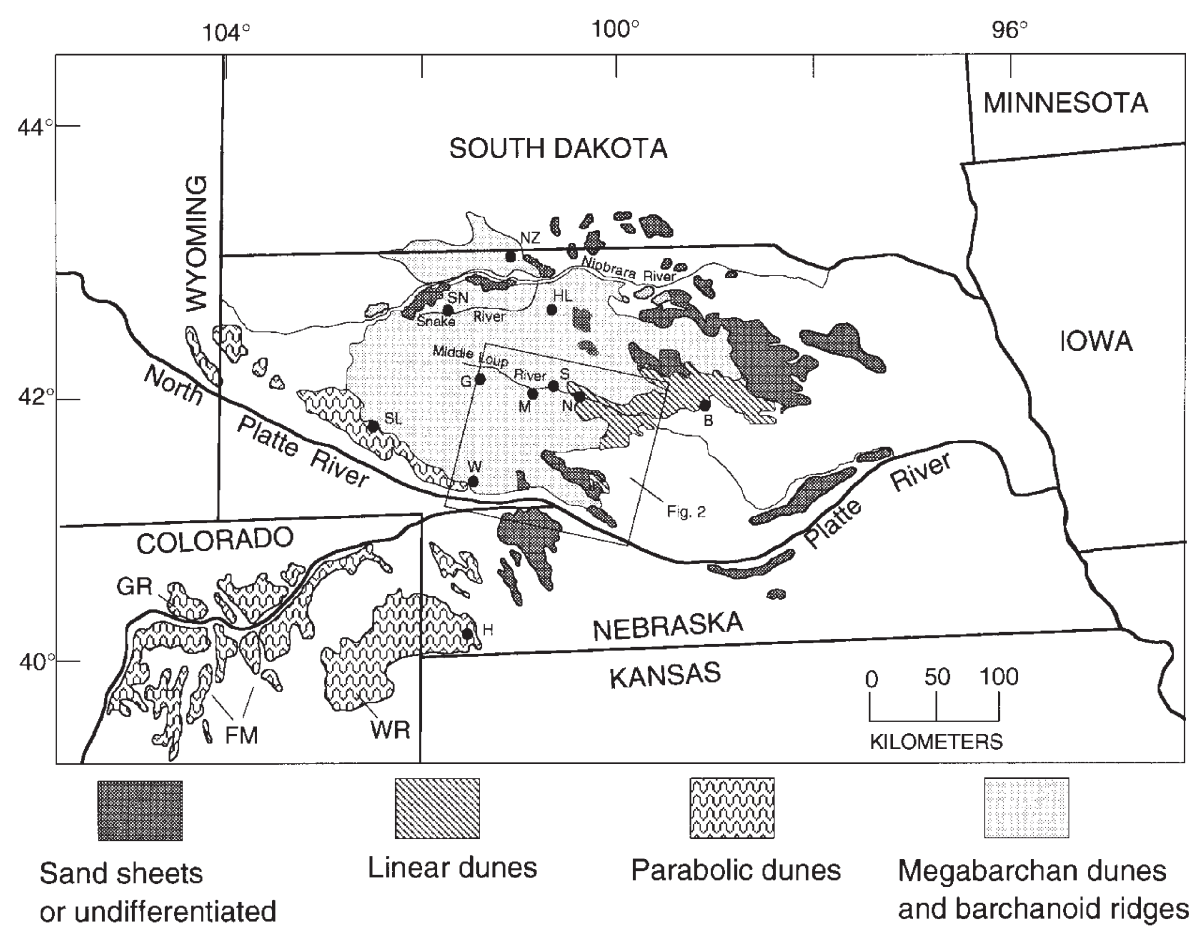

FIG. 1. Map showing distribution of eolian sand and bedform types in Nebraska, Colorado, and portions of adjacent states, and radiocarbon localities. Eolian sand distribution and bedform types compiled from Swinehart (1990), Swinehart et al. (1994), and Muhs et al. (1996a). Localities mentioned in text: GR, Greeley dune field; FM, Fort Morgan dune field; WR, Wray dune field; SN, Snake River; S, Seneca; M, Quarry near Mullen; N, Natick; W, Whitetail Creek; H, Hoover blowout; G, Gudmundsen; NZ, Nenzel; B, Burwell; SL, Swan Lake; HL, Hackberry Lake.

gators present ${ }^{14} \mathrm{C}$ data supporting several periods of dune movement within the past $8000 \mathrm{yr}$ (Ahlbrandt et al., 1983; Swinehart and Diffendal, 1990; Loope et al., 1995). A Holocene age for the most recent episodes of dune movement agrees with studies of dune fields elsewhere in the Great Plains, such as Texas and New Mexico (Holliday, 1995, 1996), Kansas (Arbogast, 1996), Colorado (Madole, 1995; Forman et al., 1995; Muhs et al., 1996a), North Dakota (Running and Boughton, 1996; Muhs et al., 1996b), Saskatchewan (Wolfe et al., 1995), and Manitoba (David, 1971a). In an intermediate position, Smith (1965) and Wright et al. (1985) hypothesized that the principal dune forms in the Nebraska Sand Hills are Pleistocene, but there may have been intensive Holocene reactivation in some areas. Recently, Loope et al. (1995) and Mason et al. (1997) conclude that eolian sand blocked drainages within the Sand Hills during both the late Pleistocene and the middle Holocene.

The timing of past eolian deposition is important for predicting the degree of activity in the future. Dunes in most parts of the Great Plains, including the Nebraska Sand Hills, are presently inactive and stabilized by prairie vegetation. If the dunes are primarily an ice-age relic, then reactivation in the near future is unlikely. On the other hand, if the dunes were active during the Holocene, then future climatic conditions, whether due to natural variability or to human causes (such as greenhouse warming), may bring about re- newed eolian activity. Higher temperatures, combined with significant reductions in precipitation, would reduce vegetation cover and could therefore bring about reactivation of many currently stabilized dunes (Muhs and Maat, 1993).

\section{METHODS}

In the Nebraska Sand Hills, we found bones of bison and smaller, unidentified mammals. These bones either underlie eolian sands or occur in paleosols within eolian sands. Skeletal elements were identified taxonomically as Bison spp. Bison bones are ideal for ${ }^{14} \mathrm{C}$ dating because they are taxonomically distinct and large enough to preclude most vertical postdepositional movement. The accuracy of bone ${ }^{14} \mathrm{C}$ ages is very high because (1) simultaneous advancements in AMS physics and bone dating chemistry (Stafford et al., 1987, 1991) provide protocols for obtaining accurate bone collagen ages, (2) the bison bones dated in this study were physically and chemically very well preserved, based on $\mathrm{C}, \mathrm{N}$, and amino acid concentrations (Table 1), and (3) two drastically different chemical fractions were analyzed (Stafford et al., 1987), thus allowing cross-checks on whether the bones experienced closed-system conditions with respect to carbon. Organic-rich alluvium (humic acid fraction) was also dated at two localities; details of the extraction methods are outlined in Abbott and Stafford (1996). Stable carbon and nitro- 


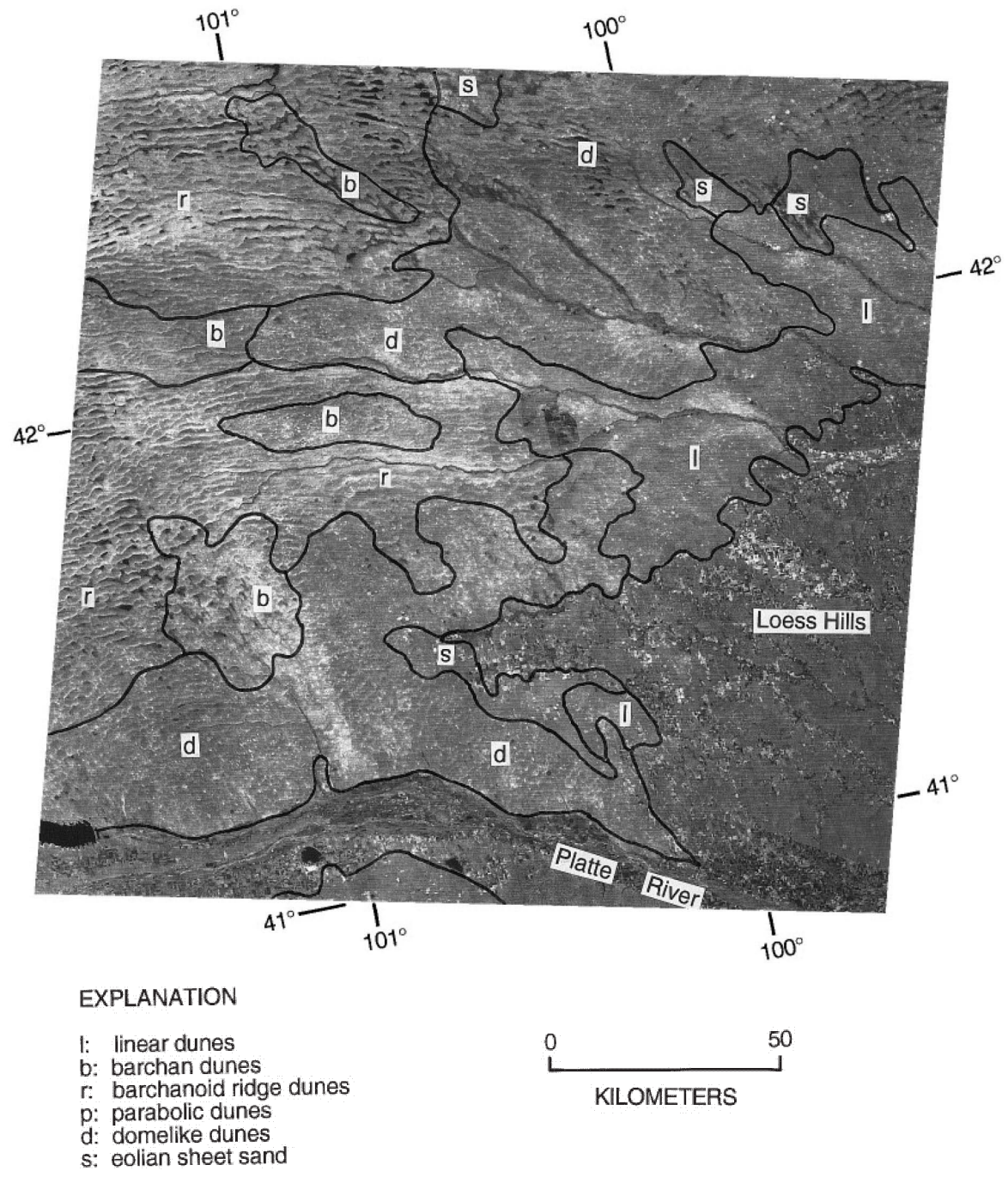

FIG. 2. Landsat MSS 5 image of the central and eastern portion of the Nebraska Sand Hills, showing various types of eolian bedforms. Eolian bedform types from Swinehart et al. (1994).

gen isotopic compositions of the bones were determined by mass spectrometry; previous studies have shown that the $\mathrm{C}$ and $\mathrm{N}$ isotopic composition of bone reflects the isotopic composition of the plants comprising the animal's diet (Hare et al., 1991). Mineralogical and geochemical studies of the Nebraska dune sands and possible source sediments were conducted using X-ray diffraction and energy-dispersive Xray fluorescence methods following those outlined by Muhs et al. $(1995,1996 a)$.

\section{STRATIGRAPHY AND RADIOCARBON AGES}

\section{Eolian Sand Deposition in the Past 3000 yr}

New evidence was found of eolian sand deposition in the past $3000 \mathrm{yr}$ at three widely separated localities in the Nebraska Sand Hills. In the southwestern Sand Hills, headward erosion by Whitetail Creek, northeast of Ogallala, has exposed sediments in an area of dome-like dunes that have been reworked into parabolic dunes (Fig. 1). Field relations suggest that the present channel of Whitetail Creek postdates some of these parabolic dunes. We studied exposures in this area that had previously been described by Ahlbrandt et al. (1983) and May et al. (1995). On both sides of Whitetail Creek, 5$6 \mathrm{~m}$ of eolian sand are underlain by $2-3 \mathrm{~m}$ of paludal (?) sandy silts which are in turn underlain by up to $20 \mathrm{~m}$ of Pliocene sand sheet deposits (Fig. 3). Radiocarbon ages of bison bone from both sides of Whitetail Creek support the interpretation that eolian sedimentation began sometime between $\sim 2900$ and $\sim 2000{ }^{14} \mathrm{C}$ yr B.P. Eolian sedimentation was still in progress at $\sim 2000{ }^{14} \mathrm{C}$ yr B.P. Both sections contain buried soils above the dated bones that have weak, $\mathrm{A} / \mathrm{AC} / \mathrm{C}$ profiles, indicating two periods of eolian deposition. 
TABLE 1

Analytical Data for Fossil Bones from Nebraska

\begin{tabular}{|c|c|c|c|c|c|c|c|c|c|c|c|c|}
\hline LLNL no. ${ }^{a}$ & $\begin{array}{c}\text { INSTAAR } \\
\text { no. }{ }^{b}\end{array}$ & Loc. & $\begin{array}{l}\mathrm{C} \\
(\%)\end{array}$ & $\begin{array}{l}\mathrm{N} \\
(\%)\end{array}$ & $\begin{array}{c}\text { AA/bone }^{c} \\
(\mathrm{~nm} / \mathrm{mg})\end{array}$ & Fraction $^{d}$ & $\begin{array}{l}\delta^{13} \mathrm{C} \\
(\%)\end{array}$ & $\begin{array}{l}\delta^{15} \mathrm{~N} \\
(\% \mathrm{o})\end{array}$ & $\mathrm{Fm}^{e}$ & Error & $\begin{array}{l}{ }^{14} \mathrm{C} \text { age } \\
\text { (yr B.P.) }\end{array}$ & $\begin{array}{c}\text { Cal. age }(2 \delta)^{f} \\
\quad(\text { yr B.P.) }\end{array}$ \\
\hline CAMS-3496 & NSRL-407 & Hoover & 12.23 & 3.97 & 1536 & Coll. & -11.7 & +5.1 & 0.9564 & 0.0067 & $360 \pm 60$ & $515-290$ \\
\hline CAMS-3491 & NSRL-406 & $\begin{array}{l}\text { Seneca central, } \\
\text { upper soil }\end{array}$ & 11.89 & 3.89 & 1766 & Coll. & -15.7 & +3.4 & 0.9730 & 0.0103 & $220 \pm 60$ & $478-0$ \\
\hline CAMS-5302 & NSRL-406 & & & & & Carb. & -8.3 & & 0.9727 & 0.0068 & $220 \pm 90$ & $478-0$ \\
\hline CAMS-5303 & NSRL-408 & & & & & Carb. & -5.1 & & 0.9450 & 0.0095 & $450 \pm 90$ & $640-299$ \\
\hline CAMS-3494 & NSRL-411 & Seneca east & 7.62 & 2.24 & 954 & Coll. & -13.1 & +5.3 & 0.9715 & 0.0072 & $230 \pm 60$ & $435-0$ \\
\hline CAMS-5309 & NSRL-411 & & & & & Carb. & -5.7 & & 0.9704 & 0.0094 & $240 \pm 80$ & $479-0$ \\
\hline CAMS-3495 & NSRL-443 & Mullen quarry & 8.05 & 2.79 & 770 & Coll. & -7.3 & +4.0 & 0.9343 & 0.0099 & $550 \pm 90$ & $665-339$ \\
\hline CAMS-5310 & NSRL-443 & & & & & Carb. & -0.1 & & 0.9285 & 0.0066 & $600 \pm 60$ & $663-514$ \\
\hline CAMS-3492 & NSRL-409 & $\begin{array}{l}\text { White-tail } \\
\text { Creek, west }\end{array}$ & 3.54 & 0.74 & 205 & Coll. & -9.8 & +3.9 & 0.7735 & 0.0054 & $2060 \pm 60$ & $2146-1874$ \\
\hline CAMS-5311 & NSRL-410 & & & & & Carb. & -1.6 & & 0.7002 & 0.0050 & $2860 \pm 60$ & $3202-2797$ \\
\hline
\end{tabular}

${ }^{a}$ Lawrence Livermore National Laboratory number.

${ }^{b}$ Institute of Arctic and Alpine Research (University of Colorado) laboratory number.

${ }^{c}$ Total amino acid concentration per unit of bone.

${ }^{d}$ Coll., purified collagen; Carb., carboxyl $\mathrm{CO}_{2}$ fraction.

${ }^{e} \mathrm{Fm}$, fraction of modern ${ }^{14} \mathrm{C}$ content.

${ }^{f}$ Calendar age (calibrated from Stuiver and Pearson, 1993; Pearson and Stuiver, 1993).

Much of the northwestern and central part of the Sand Hills is characterized by complex megabarchan and barchanoid-ridge dunes (Swinehart, 1990). East-west-trending barchanoid-ridge dunes are $20-40 \mathrm{~km}$ long and correspond to Smith's (1965) "Series I" dunes. The Snake River, a tributary to the Niobrara River (Fig. 1), traverses the northwestern part of this dune belt and parallels the south-facing slip face of a barchanoid ridge that is at least $12 \mathrm{~km}$ long. Typical of many barchanoid ridges in this area, the surface of this dune has been extensively reworked into small parabolic dunes (Smith's (1965) "Series III" dunes), which are themselves highly reworked. It cannot be ascertained either from field observations or from aerial photograph interpretation whether the section examined is part of the older barchanoid ridge or a younger parabolic dune, but the latter is more likely. Organic-rich silts in the terrace alluvium that underlies the eolian sand were dated. The uppermost organic-rich bed dates the beginning of eolian activity to sometime after $\sim 2700{ }^{14} \mathrm{C}$ yr B.P. The presence of a bioturbated paleosol in the eolian sands indicates that there were two phases of eolian deposition. Ahlbrandt et al. (1983) report ages of 940 $\pm 55{ }^{14} \mathrm{C}$ yr B.P. (no $\mathrm{NaOH}$ treatment) and $780 \pm 60{ }^{14} \mathrm{C}$ yr B.P. ( $\mathrm{NaOH}$ treatment) for organic-rich alluvium that underlies eolian sand at a locality on the Snake River $\sim 10 \mathrm{~km}$ west of our locality. Because the uppermost dated alluvium at the new locality is a maximum-limiting age, the eolian sand here may also be only a few hundred years old.

Belts of linear dunes and much smaller (generally $<0.5$ $\mathrm{km}$ ), northwest-trending parabolic dunes occur immediately north and south of the Middle Loup River in the central Sand Hills (Figs. 1 and 2). Some of these small linear and parabolic dunes occur on top of much larger east-west-trending barchanoid ridges and therefore postdate the larger dunes. It is not clear from geomorphic relations whether the parabolic dunes are younger, older, or about the same age as the longer linear dunes, but both dune types have weakly expressed $\mathrm{A} / \mathrm{AC} / \mathrm{C}$ soil profiles, suggesting broadly similar ages. The Natick locality, described earlier by Ahlbrandt et al. (1983), is a cutbank of the Middle Loup River on the nose of a northwest-trending compound parabolic dune (Fig. $3)$. The locality exposes eolian sand underlain by alluvium that contains several organic-rich beds. A new AMS ${ }^{14} \mathrm{C}$ age for organic matter in the lowest alluvial unit substantiates eolian activity beginning sometime after $\sim 2600{ }^{14} \mathrm{C}$ yr B.P., in broad agreement with a previous age reported by Ahlbrandt et al. (1983).

\section{Eolian Deposition in the Past 1000 yr}

The central Nebraska Sand Hills area has many complex dunes, with parabolic or linear dunes being superimposed 
WHITETAIL CREEK WEST
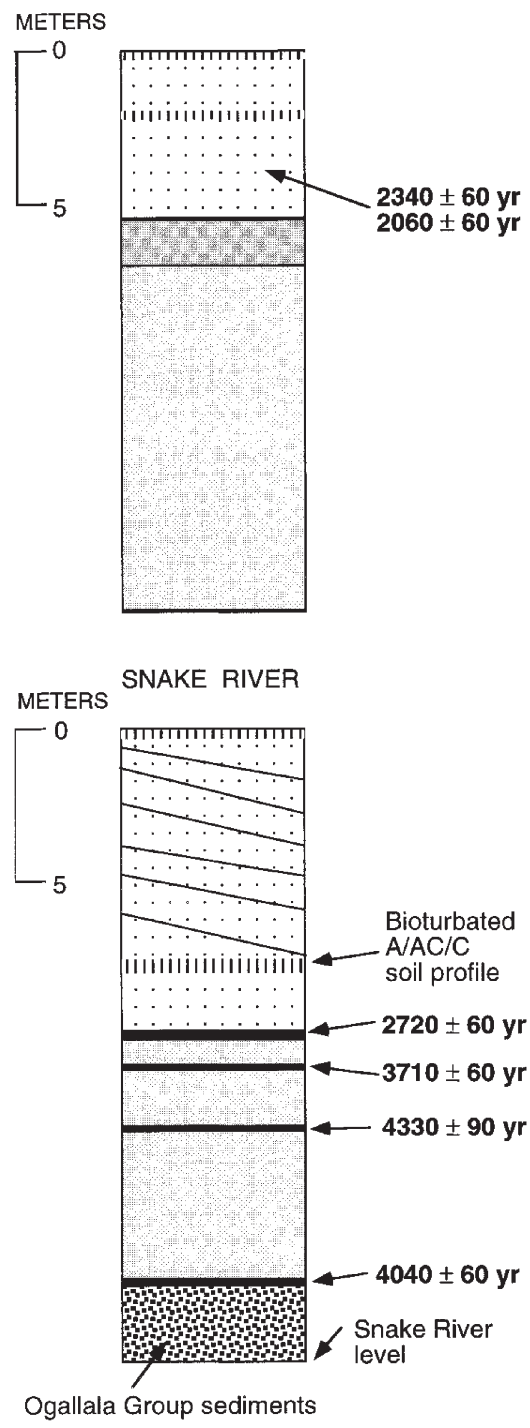

WHITETAIL CREEK EAST

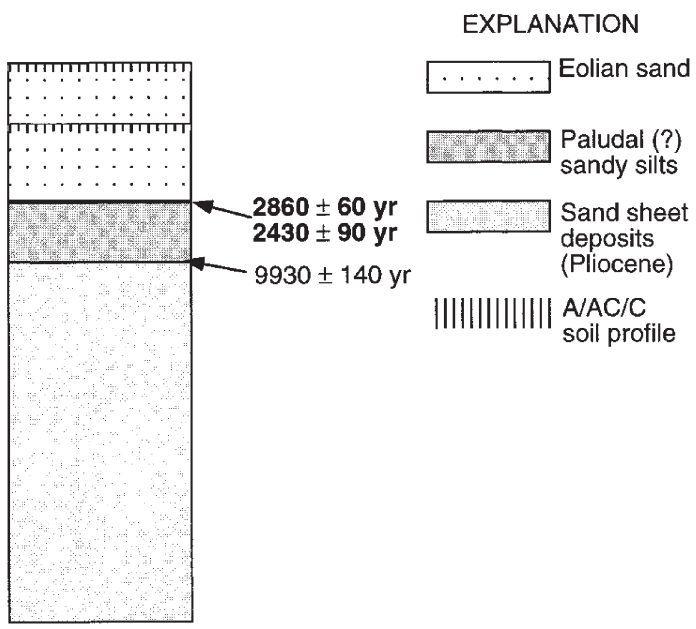

NATICK

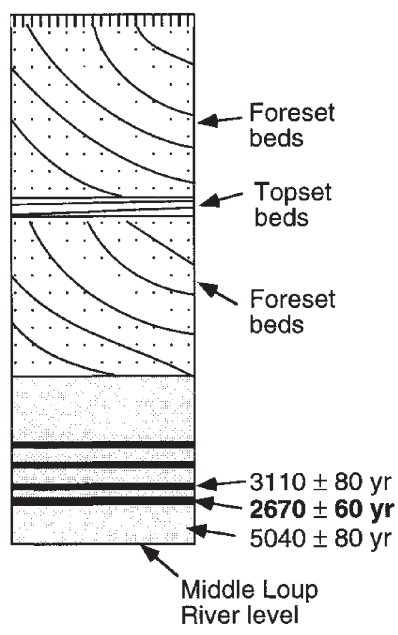

EXPLANATION

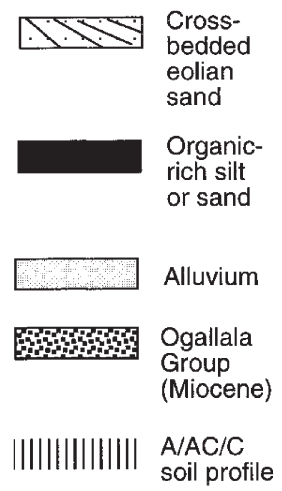

FIG. 3. Stratigraphy of eolian sand and underlying deposits and radiocarbon ages of bones and organic matter at the Whitetail Creek, Snake River, and Natick localities. Where pairs of numbers are shown, the top number is carboxyl radiocarbon age of bone and the bottom number is collagen radiocarbon age of same bone. Ages in bold numerals are those from this study; others are from Ahlbrandt et al. (1983).

on larger, older barchans. The youngest of these indicate eolian deposition in the past millennium. Near Seneca, Nebraska, we examined a series of exposures on the southeastern part of a dome-like dune that could be a highly modified barchan. The eolian sands near Seneca and in a quarry near Mullen $\sim 12 \mathrm{~km}$ farther west have as many as three weakly developed paleosols with $\mathrm{A} / \mathrm{AC} / \mathrm{C}$ profiles. Based on our new AMS ages of bison bone, there have been at least three, and possibly four cycles of eolian sand movement and soil formation during the past $\sim 800{ }^{14} \mathrm{C} \mathrm{yr}$ (Fig. 4). These ages are in accord with the conclusions of Stokes and Swinehart (1997), who report optically stimulated luminescence (OSL) ages for this locality.
Numerous smaller dune fields are found outside of the Nebraska Sand Hills in Nebraska and adjacent Colorado (Fig. 1). The largest of these sand bodies is the Wray dune field, which consists primarily of parabolic and compound parabolic dunes (Madole, 1995; Muhs et al., 1996a). In the eastern part of the Wray dune field a 16-m-deep deflation hollow called the Hoover blowout (Madole, 1995) exposes $\sim 8 \mathrm{~m}$ of eolian sand within the nose area of a northwesttrending compound parabolic dune (Fig. 4). The eolian sands contain two buried soils with $\mathrm{A} / \mathrm{AC} / \mathrm{C}$ profiles and are underlain by pond or lacustrine sands, silts, and clays. From the radiocarbon ages reported by Madole (1995) and a new age on bone that we report here, we infer that eolian sedimenta- 


\section{MULLEN QUARRY SENECA WEST SENECA CENTRAL SENECA EAST}

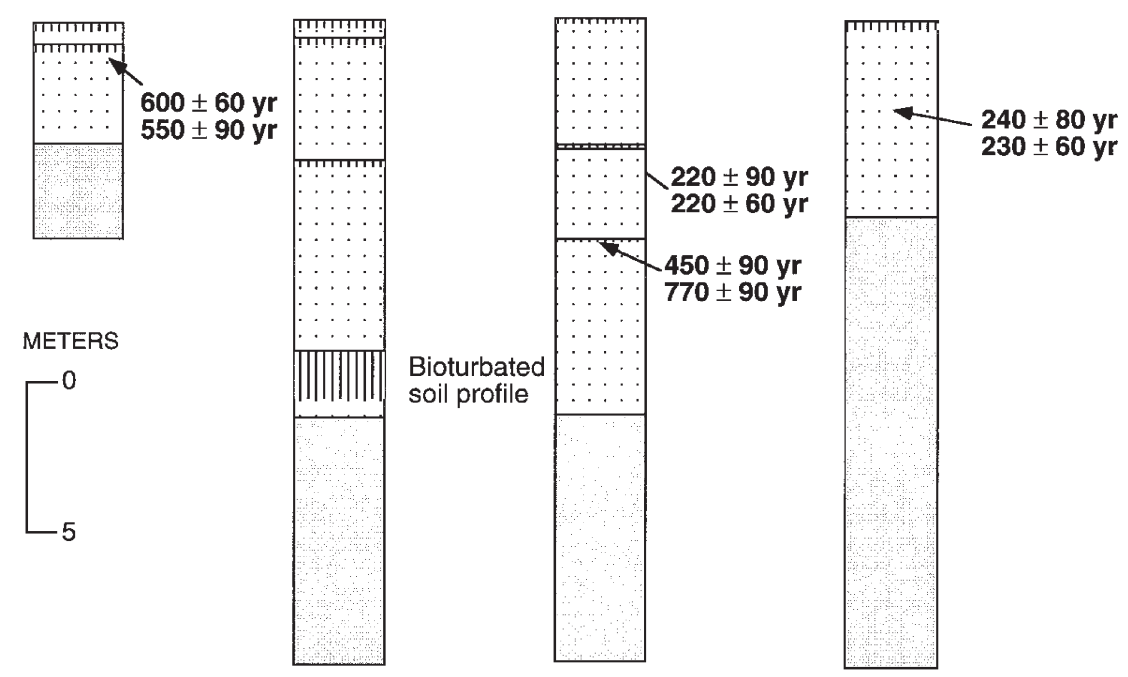

HOOVER BLOWOUT
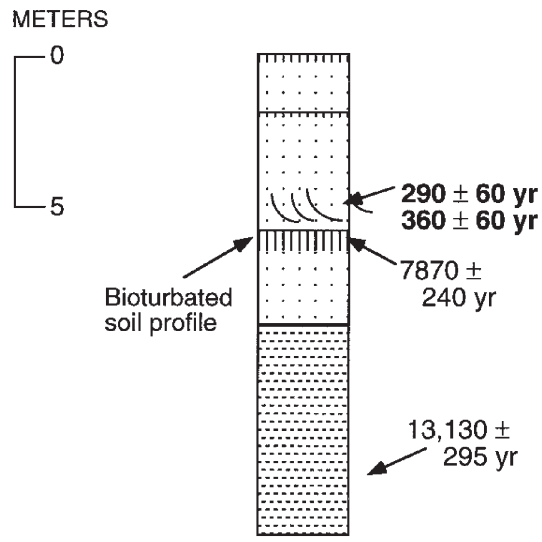

EXPLANATION

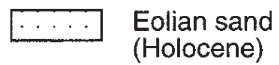

Paludal or lacustrine

sediments (Pleistocene)

Eolian sheet

sand (Pliocene)

||||||||||| A/AC/C soil profile

FIG. 4. Stratigraphy of eolian sand and underlying deposits at the Seneca, Mullen quarry, and Hoover blowout localities. Where pairs of numbers are shown, the top number is carboxyl radiocarbon age of bone and bottom number is collagen radiocarbon age of same bone. Single radiocarbon ages, not in bold text, at the Hoover blowout locality are from Madole (1995).

tion at this locality began sometime after $\sim 13,000{ }^{14} \mathrm{C}$ yr B.P. and was episodic, based on the presence of the two buried soils (Fig. 4). The two most recent episodes of eolian sedimentation began sometime after $\sim 7900{ }^{14} \mathrm{C}$ yr B.P. and apparently occurred within the past $\sim 400 \mathrm{yr}{ }^{14} \mathrm{C}$ yr B.P. Thus, our new data indicate that the Wray dune field, like the Nebraska Sand Hills, has been active in the past millennium, consistent with the conclusions of Madole (1995).

\section{Carbon Isotopes as Indicators of Nebraska Sand Hills Vegetation in the Past $3000 \mathrm{yr}$}

The vegetation of the Nebraska Sand Hills about 1850 A.D., prior to major settlement, was Sand Hills prairie. This grassland assemblage contains elements of both tallgrass bluestem prairie (Andropogon-Panicum-Sorghastrum), found to the east, and shortgrass prairie (Bouteloua-Buchloe), found to the west (Kuchler, 1964; Kaul, 1990). Mixed prairie (AgropyronAndropogon-Stipa) is found to the northeast and southeast of the Sand Hills, but what Kaul (1990) refers to as Dakota prairie (Agropyron-Stipa) is found to the north of most of the dune field. Pollen studies at Swan Lake and Hackberry Lake (Fig. 1) indicate that prairie vegetation of some kind has been dominant over the southwestern Sand Hills since at least $9000{ }^{14} \mathrm{C}$ yr B.P. (Wright et al., 1985) and over the northern Sand Hills since at least $5000{ }^{14} \mathrm{C}$ yr B.P. (Sears, 1961).

Carbon isotopic compositions of the dated bones are consistent with the grassland vegetation that has characterized the past few thousand years in the region. Two types of 


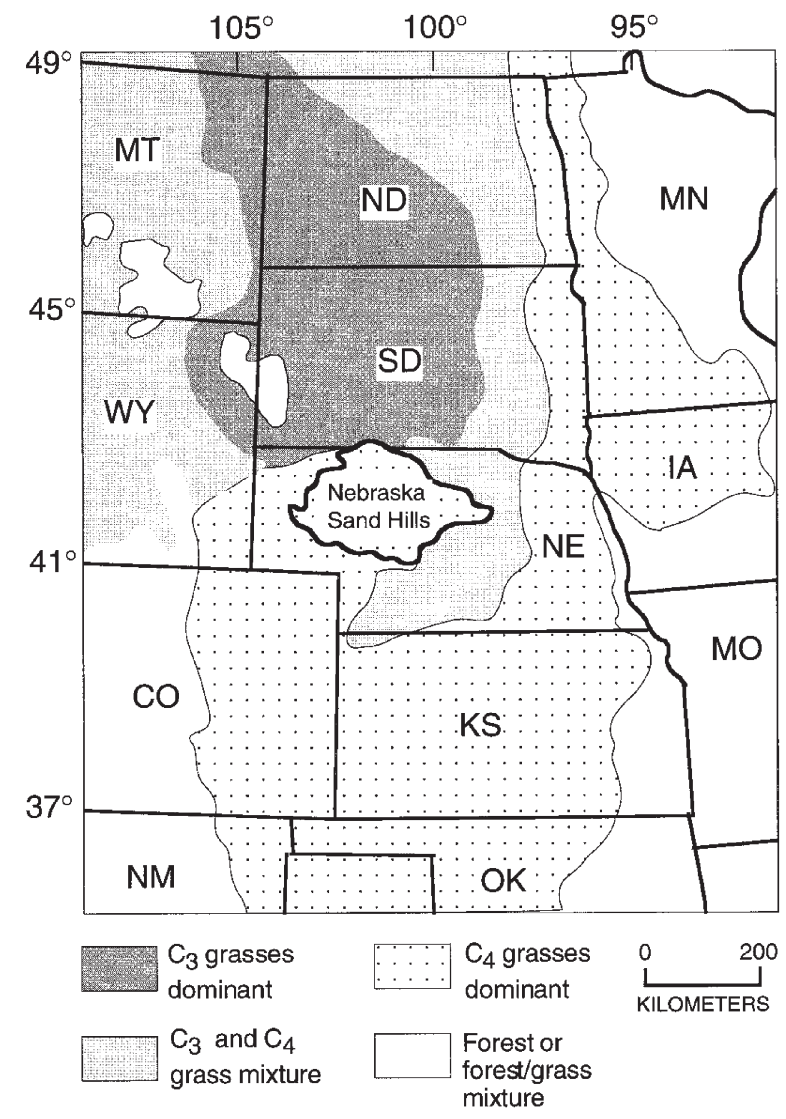

FIG. 5. Map showing distribution of grassland types (expressed as $\mathrm{C}_{3}$ vs $\mathrm{C}_{4}$ photosynthetic pathways) in the central and northern Great Plains (Kuchler, 1964; Kaul, 1990).

photosynthetic pathways, $\mathrm{C}_{3}$ and $\mathrm{C}_{4}$, fractionate carbon isotopes in distinctly different ways. $\mathrm{C}_{3}$ plants, which include both cool-summer grasses and all trees, have $\delta^{13} \mathrm{C}$ values that range from about $-22 \%$ to about $-34 \%$ and average about $-26 \%$, whereas $\mathrm{C}_{4}$ plants, which include most warm summer grasses, range from about $-9 \%$ to about $-20 \%$ and average about $-12 \%$ (O'Leary, 1988). Teeri and Stowe (1976) found that the relative proportion of $\mathrm{C}_{4}$ grasses in North America is positively correlated with summer temperatures and length of growing season. The northern Great Plains area is dominated by cool-summer $\mathrm{C}_{3}$ grasses, and the central and southern Great Plains region, including the Nebraska Sand Hills, is dominated by warm-summer $\mathrm{C}_{4}$ grasses (Fig. 5).

Experimental studies have shown that the $\delta^{13} \mathrm{C}$ values of bone collagen reflect the carbon isotopic composition of plants in an animal's diet (Hare et al., 1991). Therefore, $\delta^{13} \mathrm{C}$ values of bison collagen can provide information on the relative proportions of $\mathrm{C}_{3}$ and $\mathrm{C}_{4}$ grasses that were in the grazing environment of the animals. The $\delta^{13} \mathrm{C}$ values of bone collagen from Nebraska we studied range from -7.3 to $-15.7 \%$ and are thus consistent with $\mathrm{C}_{4}$ grasslands (Fig. 6;
Table 1). These values are similar to those reported by Madole (1995) for buried soil A horizons in eolian sand of late Holocene age in northeastern Colorado, and are distinct from those reported by David (1971a,b) for buried soil A horizons from the Brandon Sand Hills of Manitoba, where $\mathrm{C}_{3}$ grasses are more abundant. Collectively, the data suggest that $\mathrm{C}_{4}$ dominated grasslands, similar to those of today, prevailed over much of the central Great Plains region of Nebraska and Colorado during the past $\sim 3000 \mathrm{yr}$.

\section{MINERALOGY AND GEOCHEMISTRY OF THE NEBRASKA SAND HILLS}

We conducted mineralogical and geochemical studies of the Nebraska Sand Hills and made comparisons to dune fields in northeastern Colorado (Muhs et al., 1996a), as well as possible source sediments, in order to assess the degree of mineralogical maturity of this sand sea. Mineralogical maturity in sandstones or sandy sediments derived from crystalline rocks is characterized by an abundance of quartz and depletion of feldspars (Blatt et al., 1972). By this definition, many of the world's largest sand seas are mineralogically mature (Cooke and Warren, 1973; McKee, 1983; Pye and Tsoar, 1990). The degree of mineralogical maturity in the Nebraska Sand Hills is important because it has significance for the long-term evolution of the dune field.

\section{Nebraska Sand Hills Compared to Colorado Dunes}

Compared to dune fields in eastern Colorado, derived from South Platte River sediments, Nebraska dunes are enriched in quartz and depleted in K-feldspar, with approximately equal amounts of plagioclase (Fig. 7). Because X-ray diffraction is a semiquantitative technique, we also determined $\mathrm{K}_{2} \mathrm{O}, \mathrm{Ba}$, and $\mathrm{Rb}$ concentrations in these samples. Barium and rubidium are trace elements that usually substitute for

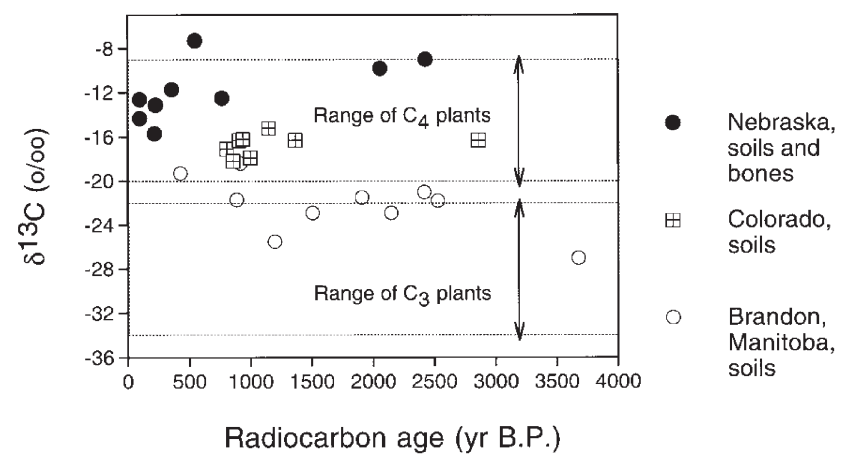

FIG. 6. Plot of $\delta^{13} \mathrm{C}$ values in modern Sand Hills grasslands soils (data from Steuter et al., 1990) and in bison bones from Nebraska (this study) as a function of AMS radiocarbon age. Shown for comparison are $\delta^{13} \mathrm{C}$ values for buried soils in eolian sand in eastern Colorado (Madole, 1995) and southern Manitoba (David, 1971a,b) and ranges of $\delta^{13} \mathrm{C}$ values for $\mathrm{C}_{3}$ and $\mathrm{C}_{4}$ plants (O’Leary, 1988). 
TABLE 2

Analytical Data for Organic Matter-Rich Alluvium from Nebraska

\begin{tabular}{|c|c|c|c|c|c|c|c|}
\hline LLNL no. $^{a}$ & $\begin{array}{l}\text { INSTAAR } \\
\text { no. }^{b}\end{array}$ & Locality & $\begin{array}{l}\text { Depth } \\
\text { (m) }\end{array}$ & $\mathrm{Fm}^{c}$ & Error & $\begin{array}{l}{ }^{14} \mathrm{C} \text { age } \\
\text { (yr B.P.) }\end{array}$ & $\begin{array}{l}\text { Cal. age }(2 \delta)^{d} \\
\quad(\text { yr B.P.) }\end{array}$ \\
\hline CAMS-11333 & NSRL-1548 & Snake River & 9.5 & 0.7124 & 0.0047 & $2720 \pm 60$ & $2945-2746$ \\
\hline CAMS-11329 & NSRL-1551 & Snake River & 12.5 & 0.5831 & 0.0061 & $4330 \pm 90$ & $5254-4619$ \\
\hline CAMS-11331 & NSRL-1553 & Snake River & 17.3 & 0.6049 & 0.0041 & $4040 \pm 60$ & $4813-4358$ \\
\hline CAMS-11330 & NSRL-1556 & Natick & & 0.7169 & 0.0046 & $2670 \pm 60$ & $2868-2726$ \\
\hline
\end{tabular}

${ }^{a}$ Lawrence Livermore National Laboratory number.

${ }^{b}$ Institute of Arctic and Alpine Research (University of Colorado) laboratory number.

${ }^{c} \mathrm{Fm}$, fraction of modern ${ }^{14} \mathrm{C}$ content.

${ }^{d}$ Calendar age (calibrated from Stuiver and Pearson, 1993; Pearson and Stuiver, 1993).

$\mathrm{K}$; thus, concentrations of all three elements are indicators of the relative abundance of K-bearing minerals. Geochemical results confirm the mineralogical analyses, as Colorado dune sands have $\mathrm{K}_{2} \mathrm{O}, \mathrm{Ba}$, and $\mathrm{Rb}$ concentrations significantly greater than those of the Nebraska Sand Hills (Fig. 8).

Aerial gamma-ray surveys can be used to estimate the concentrations of $\mathrm{K}, \mathrm{U}$, and $\mathrm{Th}$ in soils. We generated a $\mathrm{K}$ concentration map from gamma-ray data in Phillips et al. (1993) with a calibrated grayscale and superimposed ground-based maps of the extent of dune sands in Nebraska and northeastern Colorado as an overlay (Fig. 9). This map shows that the Nebraska Sand Hills have lower K concentrations than dunes of northeastern Colorado or Tertiary bedrock sediment sources found to the west and northwest of the Sand Hills. The white tones for dunes in northeastern Colorado correspond to relatively high $\mathrm{K}_{2} \mathrm{O}$ concentrations, in good agreement with XRF-based measurements. In contrast, the much darker tones in the Ne- braska Sand Hills correspond to lower $\mathrm{K}_{2} \mathrm{O}$ concentrations, with the lowest values in the western and north-central parts of the Sand Hills.

Analysis of eolian sands from deep drill cores indicates that $\mathrm{K}$ depletion is characteristic of more than just surface sands. Using a hollow-stem auger, we collected eolian sand samples near the crests of two east-west trending barchanoid ridges near Nenzel and the Gudmundsen Sandhills Laboratory (Fig. 1). The stratigraphy and a maximum-limiting radiocarbon age (at a depth of $\sim 46 \mathrm{~m}$ ) of $\sim 13,000 \mathrm{yr}$ B.P. for the Gudmundsen locality have been previously reported by Swinehart (1990). Results indicate $\mathrm{K}_{2} \mathrm{O}$ concentrations very similar to those of surface samples in the Nebraska Sand Hills (Fig. 10) and indicate that deeper sediments are similarly K-depleted. We interpret these data, along with the uniformly low $\mathrm{K}_{2} \mathrm{O}$ values in the surface sediments shown in Figure 8, to indicate that the dune sands of the Nebraska Sand Hills are not only K-depleted, but well mixed.

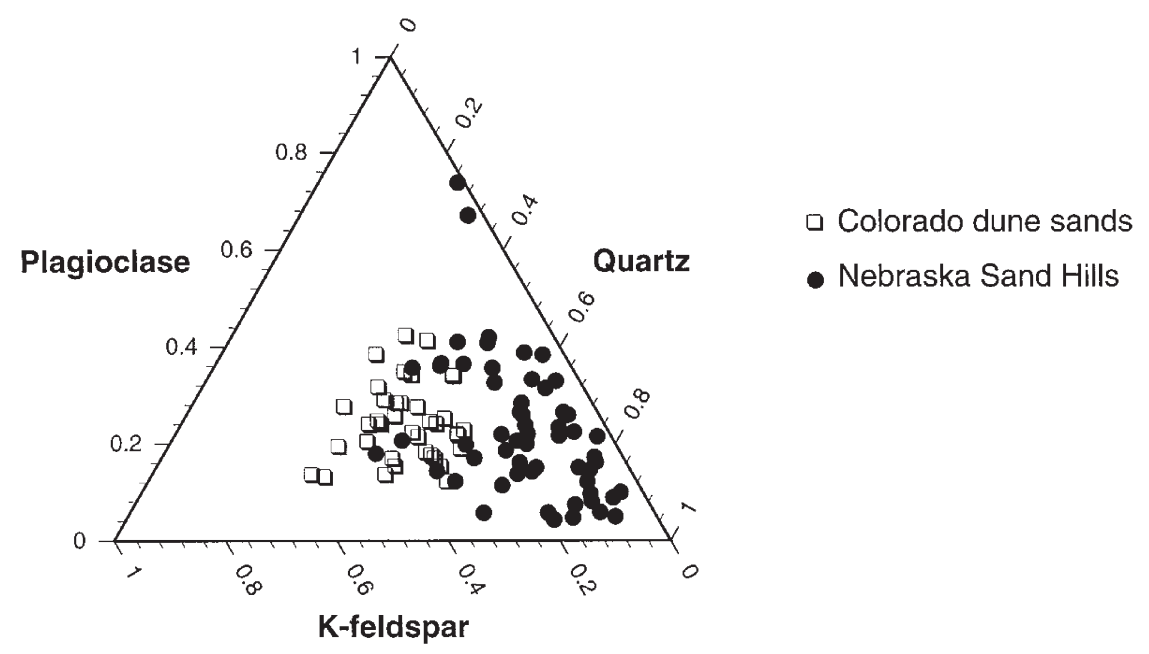

FIG. 7. Ternary plot showing relative abundances of quartz, plagioclase, and K-feldspar in the Nebraska Sand Hills compared to that seen in the Fort Morgan and Wray dune fields in Colorado. 

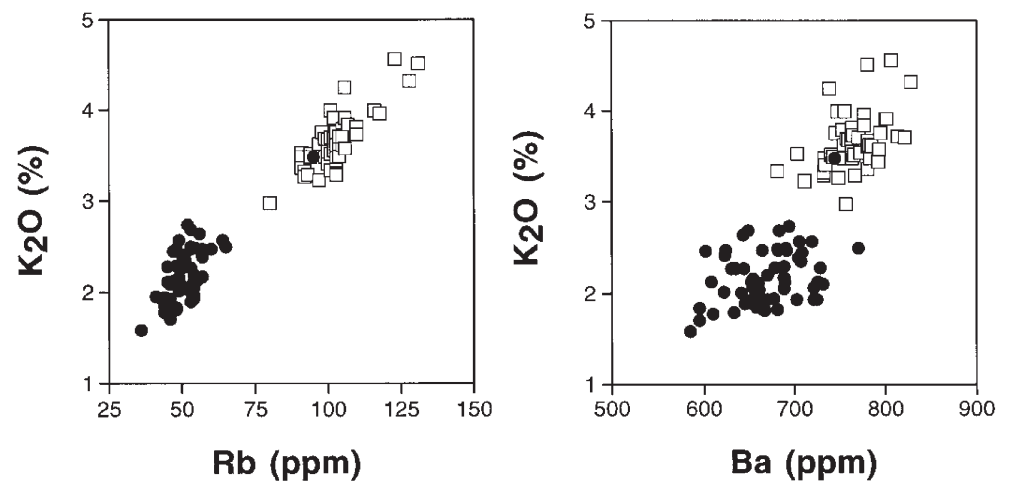

- Nebraska Sand Hills

Colorado dune sands
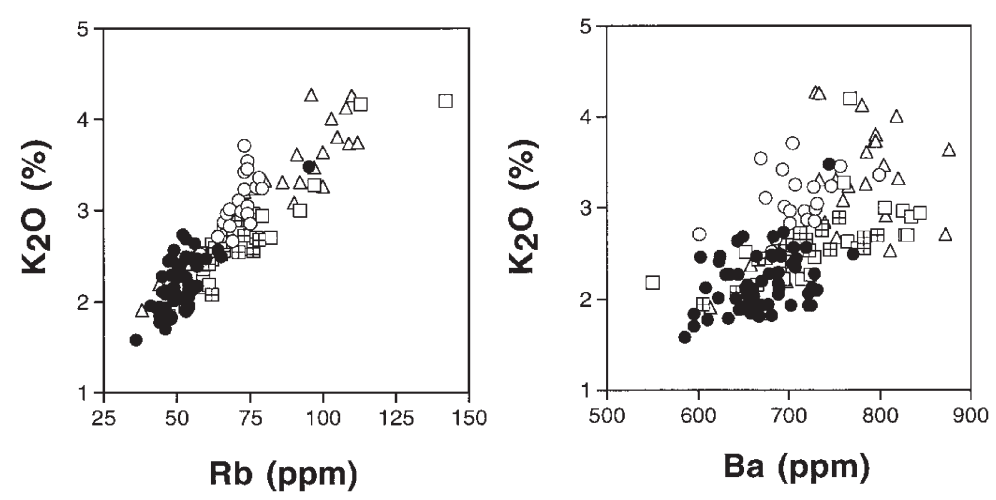

- Nebraska Sand Hills

- North Platte River sediments

Pliocene sheet sands

Ogallala Group

$\triangle \quad$ Arikaree Group

FIG. 8. Concentrations of $\mathrm{K}_{2} \mathrm{O}, \mathrm{Rb}$, and $\mathrm{Ba}$ in the Nebraska Sand Hills compared to that seen in the Wray and Fort Morgan dune fields in Colorado and possible sediment sources in Nebraska. Colorado data from Muhs et al. (1996a).

\section{Nebraska Sand Hills Compared to Source Sediments}

We also analyzed the most likely sand-bearing source sediments surrounding the Nebraska Sand Hills, as well as dominant sand-moving winds. Tertiary bedrock of the Ogallala and Arikaree groups occurs northwest of the Nebraska Sand Hills and would be a potential source of sediments with northwesterly winds, such as those that occur during the fall, winter, and spring months (Fig. 11). These sediments could have also been reworked by streams during the Quaternary and then entrained by wind. The North Platte River is west and southwest of the Nebraska Sand Hills, and downstream from its confluence with the South Platte River, the Platte River flows to the southeast of the Sand Hills. During summer months, when a monsoonal flow of air from the Gulf of Mexico penetrates the region, southeasterly winds are strong enough to deflate sediment from the Platte River northwest into the Sand Hills (Fig. 11). Sediment from the Platte River would reflect both North Platte River and South Platte River sources, but we considered the North Platte River separately in our analysis, as the composition of South Platte River sediments is indistinguishable from that of Colorado dunes (Muhs et al., 1996a). Another potential source is a predominantly eolian Pliocene sheet sand that underlies much of the Sand Hills (May et al., 1995).
A comparison of Nebraska Sand Hills sands with these possible sediment sources adds further support to the conclusion that this dune field is mineralogically mature. Arikaree Group and Ogallala Group sediments have the largest range of $\mathrm{K}_{2} \mathrm{O}$ concentrations, but most samples from these units have higher concentrations than those found in the Sand Hills (Fig. 8). North Platte River sediments have a smaller range of $\mathrm{K}_{2} \mathrm{O}$ values, but most are also higher than those found in the Sand Hills. Pliocene sheet sands have $\mathrm{K}_{2} \mathrm{O}$ concentrations that are not significantly different from the Sand Hills, but $\mathrm{Rb}$ concentrations that are mostly higher than the Sand Hills. Rb concentrations of all other sediment sources are generally higher than the Sand Hills, although Ba concentrations of all sediment groups show considerable variability. In summary, $\mathrm{K}_{2} \mathrm{O}$ and $\mathrm{Rb}$ concentrations (and to a lesser extent $\mathrm{Ba}$ concentrations) in most candidate sediment sources for the Nebraska Sand Hills support the conclusion that these eolian sands are depleted in K-feldspar.

\section{DISCUSSION}

\section{Late Holocene Radiocarbon Ages}

The new AMS radiocarbon ages demonstrate that in three widely separated localities in Nebraska, eolian sand was 


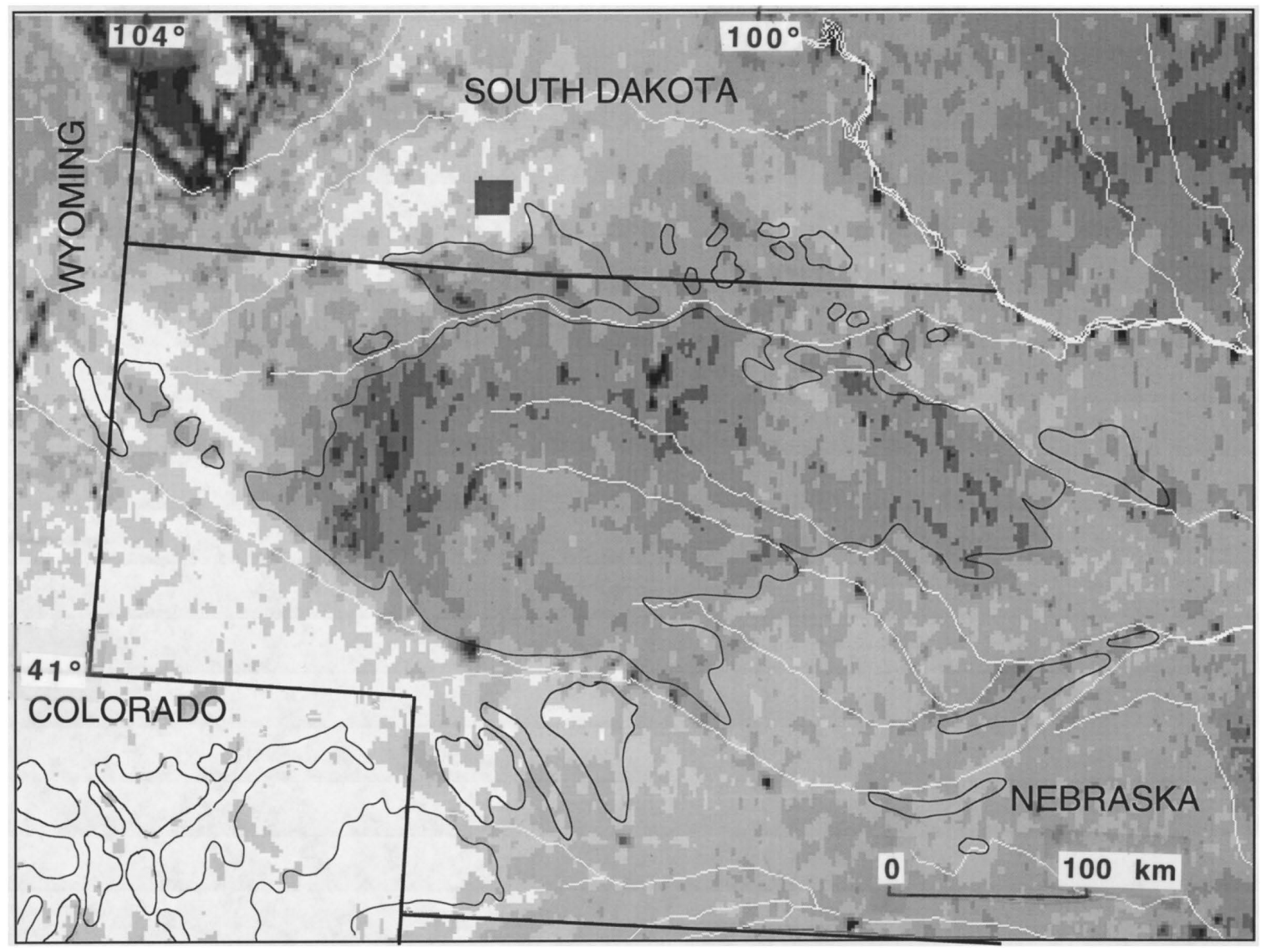

FIG. 9. Map showing relative concentrations of $\mathrm{K}$ in the Nebraska Sand Hills and surrounding areas derived from airborne gamma ray surveys. Lighter tones indicate higher concentrations of K; black lines outline dune fields. Generated from data in Phillips et al. (1993).

active in the past $3000{ }^{14} \mathrm{C}$ yr, and in three other localities, eolian sand was active in the past $800{ }^{14} \mathrm{C}$ yr. These conclusions are in agreement with new OSL ages reported by Stokes and Swinehart (1997). In addition, Muhs and Holliday (1995) presented historical evidence indicating that at least parts of the Nebraska Sand Hills may have been active during the late 1700s and 1850s A.D. Because modern winds are more than adequate for entraining sand (Fig. 11), the present stability of the Nebraska Sand Hills is due to the sparse vegetation cover. Therefore, past periods of eolian activity are indicative of severe droughts. A late Holocene record of salinity-sensitive diatoms from Moon Lake, North Dakota, shows that severe droughts (more intense than the 1930s "Dust Bowl" drought) occurred at least seven times in the past $2300 \mathrm{cal}$ yr (Laird et al., 1996). Stratigraphic and radiocarbon evidence for eolian activity after about $3000{ }^{14} \mathrm{C}$ yr B.P. from the Snake River, Natick, and Whitetail Creek localities may correlate with some of the major recorded droughts at Moon Lake in the past $\sim 2300$ cal yr.

Evidence from the Seneca, Mullen, and Hoover blowout localities indicates as many as three episodes of eolian sand movement in the past $\sim 800 \mathrm{cal} \mathrm{yr}$, and this corresponds to much of what is regarded as the Little Ice Age interval. In the Rocky Mountains of Wyoming and Colorado, the Little Ice Age is well represented by the advance of glaciers that left the Gannett Peak and Arapaho Peak moraines, respectively (Davis, 1988). It is therefore important to know if drought conditions occurred on the Great Plains during the Little Ice Age. Because the Nebraska Sand Hills lie close to the $\mathrm{C}_{4} / \mathrm{C}_{3}$ grassland boundary (Fig. 5), which is temperaturesensitive, our carbon isotope data are an important test of the hypothesis of a colder Little Ice Age climate on the Great Plains. These data show no evidence of a greater abundance of $\mathrm{C}_{3}$ grasses compared to the present (Fig. 6), indicating that temperatures were probably not significantly cooler than at present. In addition, both the Moon Lake diatom record and a diatom, ostracode, and bulk carbonate geochemistry record from Devils Lake, North Dakota, suggest several periods of aridity during the Little Ice Age on the Great Plains (Laird et al., 1996; Fritz et al., 1994). Tree-ring records from drought-sensitive red cedar and ponderosa pine in western Nebraska also show evidence of severe droughts in the past 800 cal yr (Weakly, 1962). Finally, a high-resolution sedimentary record from Elk Lake, Minnesota, shows periods of relatively high eolian sediment input during both the Little Ice Age and the period that preceded it (Dean et al., 1994). 


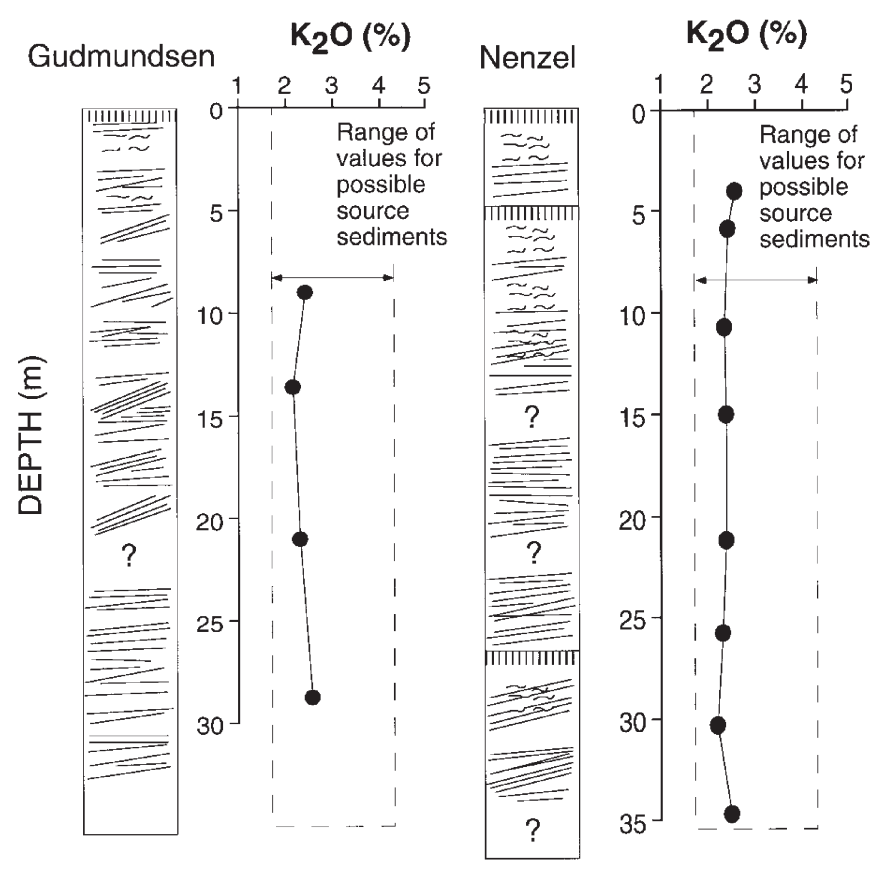

EXPLANATION

Soil or paleosol

Clay lamellae

Cross-bedded eolian sand

FIG. 10. Concentration of $\mathrm{K}_{2} \mathrm{O}$ as a function of depth in two barchanoidridge dunes (locations in Fig. 1), compared to range of values in sediment sources (Fig. 8).

Thus, the combined eolian, lacustrine, and tree-ring records indicate that there were arid periods, with temperatures no cooler than at present, on the Great Plains during the Little Ice Age advance of glaciers in Wyoming and Colorado.

\section{Significance of Weakly Developed Soils}

An important conclusion from our dating is that very weakly developed $\mathrm{A} / \mathrm{AC} / \mathrm{C}$ soil profiles can form in less than a few hundred years (Figs. 3 and 4). Soils with morphologically distinct, clay-rich Bt horizons (other than clay lamellae; cf. Ahlbrandt and Fryberger, 1980), carbonate-rich Bk horizons, or even structural or color Bw horizons in eolian sand have not been reported by soil surveyors in the Nebraska Sand Hills (Kuzila, 1990). We examined hundreds of modern soil profiles in pits, blowouts, and roadcuts throughout the Sand Hills, and all have simple, weakly expressed A/AC/C profiles. Recent dating of eolian sands in Colorado indicates that $\mathrm{Bw}$ or $\mathrm{Bt}$ horizons probably take at least a few thousand years to form (Madole, 1995; Forman et al., 1995; Muhs et al., 1996a). Collectively, these observations imply that most or all parts of the Nebraska Sand Hills were stabilized only $2000-3000{ }^{14} \mathrm{C}$ yr ago at the earliest, and probably more recently than that.

\section{Cause of Mineralogical Maturity}

Mineralogical maturity in a dune field that has been active in late Holocene time is a noteworthy phenomenon, and requires examination of possible causes. Several explanations have been offered for quartz dominance in sand seas. Some dune fields, such as the Algodones dunes of California, may be mineralogically mature because they are derived from source sediments that are themselves derived from old, multicyclic, mineralogically mature sedimentary rocks (Muhs et al., 1995). Such a mechanism does not apply to the Nebraska Sand Hills, because our comparisons indicate that all possible source sediments are more K-feldspar rich than the eolian sands.

It is possible that $\mathrm{K}$-feldspar depletion takes place in the Nebraska Sand Hills by chemical weathering when the dunes are stable. In this model, vegetation colonization stabilizes dunes and soil formation begins. Within the soil zone, chemical weathering by hydrolysis alters feldspars to clay minerals, with subsequent loss of $\mathrm{K}$ and other soluble elements. In a later phase of destabilization, feldspar-depleted sands from the soil zone are reworked into younger dunes. Repeated cycles of this process eventually lead to a feldsparpoor dune field. A problem with this process for the present Nebraska Sand Hills is that there is probably not much chemical weathering taking place in soils under prairie grass in a semiarid climate. On the other hand, chemical weathering could have taken place in the past if the Nebraska Sand Hills region supported a spruce forest, at least in valleys and interdune positions, as suggested by the pollen data of Watts and Wright (1966) and May et al. (1995). However, even under a spruce forest cover, it is not likely that chemical weathering can explain the observed K-feldspar depletion in the Nebraska Sand Hills. Colman (1982, and references therein), studying weathering rinds, established that K-feldspar shows little depletion due to chemical weathering in a wide variety of environments, including both coniferous forest and grassland, even after 100,000 yr. We conclude that chemical weathering does not explain K-feldspar depletion in the Sand Hills.

Wind abrasion can reduce sand-sized K-feldspars to silt sizes, with the result that silts are deflated away, leaving a quartz-sand-rich residue (Marsland and Woodruff, 1937; Kuenen, 1960; Greeley and Iversen, 1985). It is generally believed that sand grains in dune fields are well-rounded, and this roundness is interpreted to mean that wind abrasion is an important process in such environments. However, Goudie and Watson (1981) found that most sand grains in deserts around the world are subrounded to subangular. These data suggest that wind abrasion of grains is less important than is commonly assumed. 

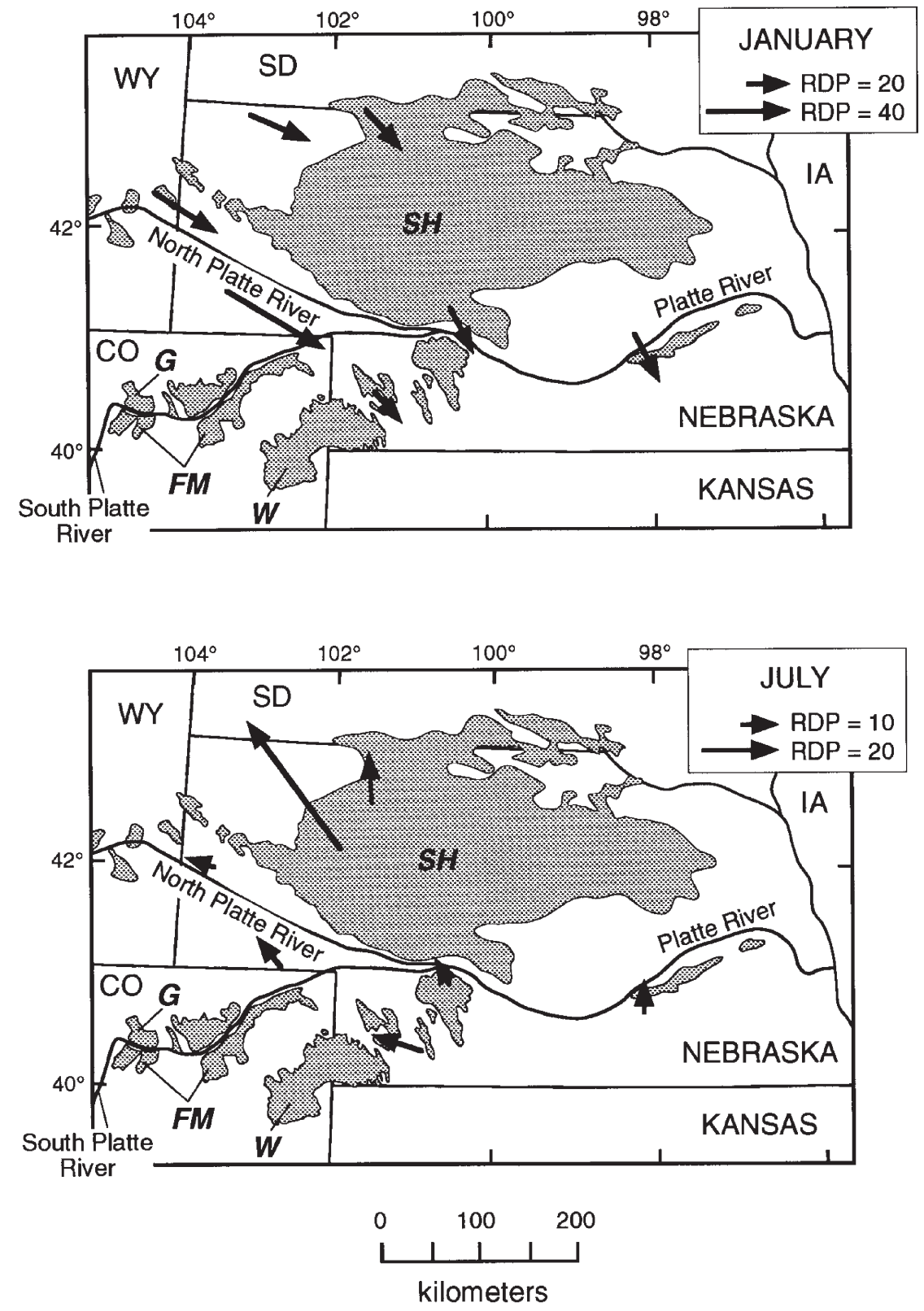

FIG. 11. Map showing resultant sand drift directions (shown by arrows) and resultant drift potentials (RDP) in vector units (shown by length of arrows) in Nebraska in January and July (terminology from Fryberger and Dean, 1979). SH, Nebraska Sand Hills; W, Wray dune field; FM, Fort Morgan dune field; G, Greeley dune field.

K-feldspar depletion may take place in the Nebraska Sand Hills while the dunes are active, but due to ballistic impacts rather than abrasion. Dutta et al. (1993) have shown on the basis of both theoretical calculations and laboratory experiments that ballistic impacts under strong $(>10 \mathrm{~m} / \mathrm{sec})$ winds can result in the mechanical breakdown of K-feldspar to silt sizes. Silt-sized K-feldspars are then removed from the dune field by suspension in wind, leaving a quartz-rich dune field. A compilation of modern data indicates that winds in the vicinity of the Nebraska Sand Hills exceed the threshold velocity for sand movement $(5 \mathrm{~m} / \mathrm{sec})$ about $40-60 \%$ of the time and exceed the ballistic impact velocity $(10 \mathrm{~m} / \mathrm{sec}) 5-$ $13 \%$ of the time. A comparison of particle size and sorting for the Nebraska Sand Hills (Ahlbrandt et al., 1980) and Colorado dune fields (Muhs et al., 1996a) indicates that Nebraska sands are in general finer grained and better sorted, which would be expected if ballistic impacts are the cause of $\mathrm{K}$-feldspar depletion in Nebraska. In addition, it is expected that if silt-sized K-feldspar grains are transported out of the Nebraska Sand Hills in suspension, downwind loess deposits should be relatively enriched in $\mathrm{K}_{2} \mathrm{O}, \mathrm{Rb}$, and $\mathrm{Ba}$. The uppermost part of Peoria (late Wisconsin) loess was sampled, below 
the zone of pedogenesis, from 45 localities downwind from the Nebraska Sand Hills in southern and southeastern Nebraska and northern Kansas in order to test this hypothesis. Results of bulk geochemical analyses indicate significantly higher $\mathrm{K}_{2} \mathrm{O}, \mathrm{Rb}$, and $\mathrm{Ba}$ contents in loess compared to the Nebraska Sand Hills, which is also supported by the gammaray map of $K$ concentrations (Fig. 9). However, while these data permit the ballistic impact hypothesis, they do not prove it. One important problem is that eolian sands tend to have low mica contents, because this platy mineral is not easily transported by saltation. In contrast, loess deposits tend to have fairly high mica contents. Therefore, part of the relatively high $\mathrm{K}_{2} \mathrm{O}, \mathrm{Rb}$, and $\mathrm{Ba}$ contents in loess may simply be due to higher mica content rather than K-feldspar content. We emphasize that our data do not suggest that the Sand Hills are the primary source of loess in Nebraska. Although new thermoluminescence and radiocarbon ages show that there are both full-glacial and Holocene loesses in Nebraska (Maat and Johnson, 1996), many loess minerals, such as micas and carbonates, are absent in the Nebraska Sand Hills, which indicates distinctly different primary sources. Achievement of mineralogical maturity by ballistic impacts is likely to be a slow process. Therefore, the low K-feldspar content of the Nebraska Sand Hills suggests that these sediments have had a long history, with many episodes of activity spanning both glacial and interglacial climates, even though they have been most recently active in the late Holocene.

\section{CONCLUSIONS}

Stratigraphic and radiocarbon data indicate that eolian sand was active in the Nebraska Sand Hills in the past 3000 ${ }^{14} \mathrm{C} \mathrm{yr}$ in some localities and in the past $800{ }^{14} \mathrm{C}$ yr in other localities. This eolian activity is due to droughts that were severe enough to remove the vegetation cover on dunes. Independent lacustrine and tree-ring records substantiate several droughts more severe than the 1930s Dust Bowl drought in the past two millennia, and it is likely that some of these were the primary cause of late Holocene eolian activity in the Nebraska Sand Hills. Carbon isotope data indicate that droughts were accompanied by temperatures similar to the present even during the Little Ice Age. Similarity of soils on dated late Holocene eolian sands with soils virtually everywhere else in the Nebraska Sand Hills yields the conclusion that this sand sea has everywhere been active at least once in the past few thousand years, though not necessarily at the same time. Despite this documentation that the Nebraska Sand Hills have been active very recently, mineralogical and geochemical data indicate that the dune field is mineralogically mature and well mixed, characterized by high quartz contents and depletion of K-feldspar. The most likely process that produced this mineralogy is ballistic impact reduction of $\mathrm{K}$-feldspar, due to strong winds over many cycles of eolian activity, probably during both glacial and interglacial periods. It is concluded, therefore, that the Nebraska Sand Hills have probably had a very long history. Based on the dual observations of recent activity and mineralogical maturity, indicating repeated cycles over a long time, the potential for reactivation of the Nebraska Sand Hills is high, with or without future greenhouse warming.

\section{ACKNOWLEDGMENTS}

This study was supported by the Global Change and Climate History Program of the U.S. Geological Survey (USGS authors) and NSF Grant EAR-9105948 (J.B.S.). We thank all of the landowners who graciously allowed access to exposures on their property. C. A. Repenning identified some of the bison bones, and R. Schumann helped generate the gammaray map of $\mathrm{K}$ concentrations. We appreciate many helpful discussions with J. N. Aleinikoff. V. T. Holliday, H. E. Wright, Jr., T. S. Ahlbrandt, and C. J. Schenk read an earlier version of this paper and offered helpful suggestions for its improvement.

\section{REFERENCES}

Abbott, M. B., and Stafford, T. W., Jr. (1996). Radiocarbon geochemistry of modern and ancient Arctic lake systems, Baffin Island, Canada. Quaternary Research 45, 300-311.

Ahlbrandt, T. S., and Fryberger, S. G. (1980). "Eolian Deposits in the Nebraska Sand Hills." U.S. Geological Survey Professional Paper 1120-A.

Ahlbrandt, T. S., Swinehart, J. B., and Maroney, D. G. (1983). The dynamic Holocene dune fields of the Great Plains and Rocky Mountain basins, U.S.A. In "Eolian Sediments and Processes" (M. E. Brookfield and T. S. Ahlbrandt, Eds.), pp. 379-406. Elsevier, New York.

Arbogast, A. F. (1996). Stratigraphic evidence for late-Holocene eolian sand mobilization and soil formation in south-central Kansas, U.S.A. Journal of Arid Environments 34, 403-414.

Blatt, H., Middleton, G., and Murray, R. (1972). “Origin of Sedimentary rocks." Prentice-Hall, Englewood Cliffs, NJ.

Colman, S. M. (1982). "Chemical Weathering of Basalts and Andesites: Evidence from Weathering Rinds." U.S. Geological Survey Professional Paper 1246.

Cooke, R. U., and Warren, A. (1973). "Geomorphology in Deserts." Univ. of California Press, Berkeley.

David, P. (1971a). The Brookdale road section and its significance in the chronological studies of dune activities in the Brandon Sand Hills of Manitoba. In Special Paper Number 9, pp. 293-299. The Geological Association of Canada.

David, P. (1971b). Harte Road, Carberry, S., and Carberry, N. E. series. Geological Survey of Canada radiocarbon dates XI. Radiocarbon 13, 255-324.

Davis, P. T. (1988). Holocene glacier fluctuations in the American Cordillera. Quaternary Science Reviews 7, 129-157.

Dean, W. E., Bradbury, J. P., Anderson, R. Y., Bader, L. R., and DieterichRurup, K. (1994). "A High-Resolution Record of Climatic Change in Elk Lake, Minnesota for the Last 1500 Years." U. S. Geological Survey Open-File Report 94-578.

Dutta, P. K., Zhou, Z., and dos Santos, P. R. (1993). A theoretical study of mineralogical maturation of eolian sand. Geological Society of America Special Paper 284, 203-209.

Forman, S. L., Oglesby, R., Markgraf, V., and Stafford, T. (1995). Paleoclimatic significance of late Quaternary eolian deposition on the Piedmont 
and High Plains, central United States. Global and Planetary Change 11, 35-55.

Fritz, S. C., Engstrom, D. R., and Haskell, B. J. (1994). "Little Ice Age"” aridity in the North American Great Plains: a high-resolution reconstruction of salinity fluctuations from Devils Lake, North Dakota, USA. The Holocene 4, 69-73.

Fryberger, S. G., and Dean, G. (1979). Dune forms and wind regime. In "A Study of Global Sand Seas" (E. D. McKee, Ed.), U.S. Geological Survey Professional Paper 1052, pp. 137-169.

Goudie, A. S., and Watson, A. (1981). The shape of desert sand dune grains. Journal of Arid Environments 4, 185-190.

Greeley, R., and Iversen, J. D. (1985). "Wind as a Geological Process on Earth, Mars, Venus and Titan." Cambridge Univ. Press, Cambridge.

Hare, P. E., Fogel, M. L., Stafford, T. W., Jr., Mitchell, A. D., and Hoering, T. C. (1991). The isotopic composition of carbon and nitrogen in individual amino acids isolated from modern and fossil proteins. Journal of Archaeological Science 18, 277-292.

Holliday, V. T. (1995). Late Quaternary stratigraphy of the Southern High Plains. In "Ancient Peoples and Landscapes" (E. Johnson, Ed.), pp. 289-313. Museum of Texas Tech Univ., Lubbock.

Holliday, V. T. (1996). Origin and evolution of lunettes on the High Plains of Texas and New Mexico. Quaternary Research 47, 54-69.

Kaul, R. (1990). Plants. In "An Atlas of the Sand Hills" (A. Bleed and C. Flowerday, Eds.), Resource Atlas 5a, pp. 127-142. Univ. of Nebraska, Lincoln.

Kuchler, A. W. (1964). Potential natural vegetation of the conterminous United States. American Geographical Society Special Publication 36, $1-38$.

Kuenen, Ph. H. (1960). Experimental abrasion. 4. Eolian action. Journal of Geology 68, 427-449.

Kutzbach, J. E., and Wright, H. E., Jr. (1985). Simulation of the climate of 18,000 years BP: Results for the North American/North Atlantic/European sector and comparison with the geologic record of North America. Quaternary Science Reviews 4, 147-187.

Kuzila, M. (1990). Soil associations and series. In "An Atlas of the Sand Hills" (A. Bleed and C. Flowerday, Eds.), Resource Atlas 5a, pp. 5866. Univ. of Nebraska, Lincoln.

Laird, K. R., Fritz, S. C., Maasch, K. A., and Cumming, B. F. (1996). Greater drought intensity and frequency before AD 1200 in the Northern Great Plains, USA. Nature 384, 552-554.

Loope, D. B., Swinehart, J. B., and Mason, J. P. (1995). Dune-dammed paleovalleys of the Nebraska Sand Hills: Intrinsic versus climatic controls on the accumulation of lake and marsh sediments. Geological Society of America Bulletin 107, 396-406.

Maat, P. B., and Johnson, W. C. (1996). Thermoluminescence and new ${ }^{14} \mathrm{C}$ age estimates for late Quaternary loesses in southwestern Nebraska. Geomorphology 17, 115-128.

Madole, R. F. (1995). Spatial and temporal patterns of late Quaternary eolian deposition, eastern Colorado, U.S.A. Quaternary Science Reviews 14, 155-177.

Marsland, P. S., and Woodruff, J. G. (1937). A study of the effects of wind transportation on grains of several minerals. Journal of Sedimentary Petrology 7, 18-30.

Mason, J. P., Swinehart, J. B., and Loope, D. B. (1997). Holocene history of lacustrine and marsh sediments in a dune-blocked drainage, southwestern Nebraska Sand Hills, U.S.A. Journal of Paleolimnology 17, 67-83.

May, D., Swinehart, J. B., Loope, D., and Souders, V. (1995). Late Quaternary fluvial and eolian sediments: Loup River Basin and the Sand Hills of Nebraska. In "Geologic Field Trips in Nebraska and Adjacent Parts of Kansas and South Dakota"' (C. A. Flowerday, Ed.), Guidebook 10, pp. 13-31. Conservation and Survey Division, Institute of Agriculture and Natural Resources, Univ. of Nebraska, Lincoln.

McKee, E. D. (1983). Eolian sand bodies of the world. In "Eolian Sediments and Processes" (M. E. Brookfield and T. S. Ahlbrandt, Eds.), Developments in Sedimentology 38, pp. 1-25. Elsevier, Amsterdam.

Muhs, D. R., and Maat, P. B. (1993). The potential response of Great Plains eolian sands to greenhouse warming and precipitation reduction on the Great Plains of the U.S.A. Journal of Arid Environments 25, 351-361.

Muhs, D. R., and Holliday, V. T. (1995). Evidence of active dune sand on the Great Plains in the 19th century from accounts of early explorers. Quaternary Research 43, 198-208.

Muhs, D. R., Bush, C. A., Cowherd, S. D., and Mahan, S. (1995). Geomorphic and geochemical evidence for the source of sand in the Algodones dunes, Colorado Desert, southeastern California. In "Desert Aeolian Processes" (V. P. Tchakerian, Ed.), pp. 37-74. Chapman and Hall, London.

Muhs, D. R., Stafford, T. W., Jr., Cowherd, S. D., Mahan, S. A., Kihl, R., Maat, P. B., Bush, C. A., and Nehring, J. (1996a). Origin of the late Quaternary dune fields of northeastern Colorado. Geomorphology 17, 129-149.

Muhs, D. R., Stafford, T. W., Jr., Burdett, J., Been, J., Mahan, S., and Rowland, Z. M. (1996b). Late Holocene aeolian sand deposition in the Minot dune field, North Dakota, U.S.A. In "The Canadian Association of Geographers Annual Meeting Program and Abstracts," pp. 157-158.

O'Leary, M. H. (1988). Carbon isotopes in photosynthesis. BioScience 38, 328-336.

Pearson, G. W., and Stuiver, M. (1993). High-precision bidecadal calibration of the radiocarbon time scale, 500-2500 BC. Radiocarbon 35, 2533.

Phillips, J. D., Duval, J. S., and Ambroziak, R. A. (1993). National geophysical data grids: Gamma-ray, gravity, magnetic, and topographic data for the conterminous United States. U.S. Geological Survey Digital Data Series DDS-9.

Pye, K., and Tsoar, H. (1990). "Aeolian Sand and Sand Dunes." London, Unwin Hyman.

Running, G. L., and Boughton, T. W. (1996). Late-Holocene parabolic dunes on the Sheyenne Delta, southeastern North Dakota. In "The Canadian Association of Geographers Annual Meeting Program and Abstracts," pp. 187-188.

Sarnthein, M. (1978). Sand deserts during glacial maximum and climatic optimum. Nature 272, 43-46.

Sears, P. B. (1961). A pollen profile from the grassland province. Science 134, 2038-2039.

Smith, H. T. U. (1965). Dune morphology and chronology in central and western Nebraska. Journal of Geology 73, 557-578.

Stafford, T. W., Jr., Jull, A. J. T., Brendel, K., Duhamel, R. C., and Donahue, D. (1987). Study of bone radiocarbon dating accuracy at the University of Arizona NSF accelerator facility for radioisotope analysis. Radiocarbon 29, 24-44.

Stafford, T. W., Jr., Hare, P. E., Currie, L., Jull, A. J. T., and Donahue, D. (1991). Accelerator radiocarbon dating at the molecular level. Journal of Archaeological Science 18, 35-72.

Steuter, A. A., Jasch, B., Ihnen, J., and Tieszen, L. L. (1990). Woodland/ grassland boundary changes in the Middle Niobrara Valley of Nebraska identified by $\delta^{13} \mathrm{C}$ values of soil organic matter. American Midland Naturalist 124, 301-308.

Stokes, S., and Swinehart, J. B. (1997). Middle and late Holocene dune reactivation in the Nebraska Sand Hills. The Holocene, in press.

Stuiver, M., and Pearson, G. W. (1993). High-precision calibration of the radiocarbon time scale, AD 1950-500 BC and 2500-6000 BC. Radiocarbon 35, 1-23. 
Swinehart, J. B. (1990). Wind-blown Deposits. In "An Atlas of the Sand Hills" (A. Bleed and C. Flowerday, Eds.), Resource Atlas 5a, pp. 4356. Univ. of Nebraska, Lincoln.

Swinehart, J. B., and Diffendal, R. F., Jr. (1990). Geology of the pre-dune strata. In "An Atlas of the Sand Hills" (A. Bleed and C. Flowerday, Eds.), Resource Atlas 5a, pp. 29-42. Univ. of Nebraska, Lincoln.

Swinehart, J. B., Dreeszen, V. H., Richmond, G. M., Tipton, M. J., Bretz, R., Steece, F. V., Hallberg, G. R., and Goebel, J. E. (1994). Quaternary geologic map of the Platte River $4^{\circ} \times 6^{\circ}$ quadrangle, United States. U.S. Geological Survey Miscellaneous Investigations Series Map I1420 (NK-14), scale 1:1,000,000.

Teeri, J. A., and Stowe, L. G. (1976). Climatic patterns and the distribution of $\mathrm{C}_{4}$ grasses in North America. Oecologia 23, 1-12.

Warren, A. (1976). Morphology and sediments of the Nebraska Sand Hills in relation to Pleistocene winds and the development of eolian bedforms. Journal of Geology 84, 685-700.
Watts, W. A., and Wright, H. E., Jr. (1966). Late-Wisconsin pollen and seed analysis from the Nebraska Sand Hills. Ecology 47, 202-210.

Weakly, H. E. (1962). History of drought in Nebraska. Journal of Soil and Water Conservation 17, 271-275.

Wells, G. L. (1983). Late-glacial circulation over central North America revealed by aeolian features. In "Variations in the Global Water Budget" (A. Street-Perrott, A. M. Beran, and R. Ratcliffe, Eds.), pp. 317-330. Reidel, Dordrecht.

Wolfe, S. A., Huntley, D. J., and Ollerhead, J. (1995). Recent and late Holocene sand dune activity in southwestern Saskatchewan. In "Current Research 1995B; Geological Survey of Canada," pp. 131-140.

Wright, H. E., Jr., Almendigner, J. C., and Gruger, J. (1985). Pollen diagram from the Nebraska Sandhills and the age of the dunes. Quaternary Research 24, 115-120. 